\title{
Pengaruh Faktor-Faktor Pembentuk Loyalitas Mahasiswa Universitas Terbuka
}

\author{
Devi Ayuni \\ Fakultas Ekonomi Universitas Terbuka \\ Jalan Cabe Raya, Tangerang Selatan \\ Andy Mulyana \\ Fakultas Ekonomi Universitas Terbuka \\ Jalan Cabe Raya, Tangerang Selatan \\ e-mail: mulyana@ut.ac.id
}

\begin{abstract}
Currently the learning system based on Information and Communication Technology (ICT) has been growing. The Open University (UT) has been using e-learning in the provision of learning support services. Online tutorials (Tuton) is one form of e-learning provided UT. Since the registration period of 2013.1-2014.2, the number of courses offered in Tuton increased by 11\% and participants also increased by $52 \%$. Although Tuton has been growing rapidly, the total number of students has declined from the registration period of 2013.1 to 2015.1. Such a decrease can be justified as an indicator of lack of loyalty or retention of students. The main objective of this study is to test the relationship between the antecedents of loyalty, service quality, commitment, satisfaction, and reputation. The study population comes from four faculties and one graduate program. Non probability method of sampling with judgmental sampling technique is used in this study. The minimum required sample size is 200 respondents. Survey data collection is conducted by inviting respondents by email to fill out a questionnaire online in google site. Then the data were analyzed both descriptively and quantitatively using descriptive analysis and Structural Equation Modeling (SEM). Results of hypothesis testing showed that 6 of 7 hypothesis were accepted with significant results. These sixth hypothesis are 1) the influence of the quality of services to satisfaction; 2) the effect of the reputation on the quality of services; 3) the effect of commitment to student satisfaction; 4) the effect of satisfaction on reputation; 5) the effect of satisfaction on loyalty; and 6) the effect of reputation on loyalty. As for the rejected hypothesis is the effect of reputation on commitment.

Keywords: loyalty, quality of service, commitment, satisfaction, reputation
\end{abstract}

\begin{abstract}
ABSTRAK
Saat ini sistem belajar berbasis Teknologi Informasi dan Komunikasi (TIK) semakin berkembang. Sistem belajar ini dikenal juga dengan sebutan e-learning. Universitas Terbuka, sebagai Perguruan Tinggi Negeri (PTN) yang menerapkan sistem pendidikan jarak jauh, telah menggunakan e-learning dalam penyediaan layanan bantuan belajar. Tutorial online (Tuton) merupakan salah satu bentuk e-learning yang diberikan UT. Sejak masa registrasi 2013.1-2014.2, jumlah mata kuliah yang ditawarkan dalam tuton bertambah sebesar $11 \%$ dan peserta tuton meningkat $52 \%$. Walaupun tuton telah berkembang pesat, tetapi secara total terjadi penurunan jumlah mahasiwa dari masa registrasi 2013.1 hingga 2015.1. Penurunan jumlah mahasiswa dapat dijustifikasi sebagai salah satu indikator rendahnya loyalitas atau retensi mahasiswa. Tujuan utama dari penelitian ini adalah menguji beragam relasi di antara anteseden loyalitas, yaitu kualitas jasa, komitmen, kepuasan, dan reputasi. Populasi penelitian ini adalah peserta tuton masa registrasi 2015.1 yang berasal dari 4 fakultas dan 1 program pascasarjana. Metode non probability sampling dengan teknik judgemental sampling digunakan dalam penelitian ini. Adapun ukuran sampel yang diperlukan minimum 200 responden. Pengumpulan data dilakukan secara survei
\end{abstract}


dengan mengundang responden melalui surel untuk mengisi kuesioner online dalam situs google. Kemudian data dianalisis baik secara deskriptif maupun kuantitatif menggunakan analisis deskriptif dan analisis Structural Equation Modelling (SEM). Hasil pengujian hipotesis menunjukkan 6 dari 7 hipotesis diterima dengan hasil yang signifikan. Keenam hipotesis tersebut adalah 1) pengaruh kualitas jasa terhadap kepuasan; 2) pengaruh kualitas jasa terhadap reputasi; 3) pengaruh komitmen terhadap kepuasan mahasiswa; 4) pengaruh kepuasan terhadap reputasi; 5) pengaruh kepuasan terhadap loyalitas; dan 6) pengaruh reputasi terhadap loyalitas. Adapun satu hipotesis yang ditolak adalah pengaruh komitmen terhadap reputasi.

Kata Kunci: loyalitas, kualitas jasa, komitmen, kepuasan, reputasi

\section{Pendahuluan}

Seiring dengan perkembangan Teknologi Informasi dan Komunikasi (TIK) yang semakin pesat, kebutuhan sistem belajar mengajar berbasis TIK menjadi tidak terelakkan lagi. Sistem belajar mengajar ini kemudian dikenal dengan sebutan $e$ learning. Menurut Kahiigi et al. (2007), e-learning adalah penyampaian bahan pembelajaran melalui media elektronik seperti internet, TV, CD-ROM, dan lain-lain.

Saat ini, popularitas e-learning semakin meningkat karena biaya yang rendah, ekspansi internet yang cepat, dan peningkatan permintaan sistem belajar yang inovatif (Zhang et al. 2004). Di Amerika Serikat pada tahun 2009, sekitar 12 juta dari 20.4 juta siswa program sarjana mengikuti sekurangnya satu program e-learning. Angka ini diproyeksikan mencapai 22 juta siswa di tahun 2014 (Nagel 2009).

Universitas Terbuka (UT) sebagai perguruan tinggi negeri dengan sistem pendidikan jarak jauh telah memulai e-learning sejak awal berdiri tahun 1984. Untuk melayani 579.261 mahasiswa aktif, UT menyiapkan bahan ajar berupa bahan ajar cetak dan bahan ajar non cetak. Bahan ajar cetak berbentuk Buku Materi Pokok (BMP) masing-masing matakuliah. Sedangkan bahan ajar non cetak berupa Computer Aided Instructional (CAI Interaktif), CD audio, web suplemen, dry lab, atau tutorial online (Tuton). Bentuk-bentuk bahan ajar non cetak yang disediakan UT sesuai dengan sistem e-learning menurut Kahiigi et al. (2007).

Tuton memiliki manfaat yang sangat besar untuk mahasiswa. Menurut Puspitasari dan Huda (2000) dalam Daulay dan Zaman (2012), melalui tuton interaksi mahasiswa dan tutor dapat berlangsung lebih cepat dimana mahasiswa langsung menerima jawaban, masukan atau perbaikan materi yang tidak dipahami dari tutor. Selain itu, tuton dapat dijadikan alternatif layanan tutorial bagi mahasiswa yang memerlukannya, namun layanan Tutorial Tatap Muka (TTM) tidak dapat diselenggarakan karena keterbatasan jumlah dan ketersebaran peserta serta ketersediaan tutor yang berkualitas (Dewiki dan Budiman 2004 dalam Asandimitra 2004).

Dari masa registrasi 2013.1-2014.2, jumlah matakuliah yang ditawarkan dalam tuton bertambah sebesar $11 \%$ dan peserta Tuton meningkat 52\%. Bila pada masa registrasi 2013.1 matakuliah tawar berjumlah 930, maka 2014.2 menjadi 1044. Disamping itu, jumlah mahasiswa peserta Tuton 108942 orang di tahun 2013.1, maka di akhir 2014.2 meningkat menjadi 226479 orang (Tabel 1). 
Tabel 1. Jumlah matakuliah tawar dan peserta Tuton

\begin{tabular}{ccc}
\hline Tahun & MK Tawar & Jml Peserta \\
\hline 2013.1 & 930 & 108942 \\
2013.2 & 930 & 123960 \\
2014.1 & 1021 & 222905 \\
2014.2 & 1044 & 226479 \\
\hline
\end{tabular}

Sumber: data diolah (2014)

Peningkatan jumlah peserta Tuton dapat dianggap sebagai keberhasilan UT dalam menyediakan bantuan belajar berbentuk e-learning. Walaupun tren peserta tuton terus meningkat dari tahun ke tahun, tetapi tren jumlah mahasiswa UT secara total terus menurun sejak masa registrasi 2013.1. Kontribusi penurunan jumlah mahasiswa terbesar disumbangkan oleh mahasiswa Fakultas Keguruan dan Ilmu Keguruan (FKIP). Sebaliknya jumlah mahasiswa Fakultas Matematika dan Imu Pengetahuan Alam (FMIPA), Fakultas IImu Sosial dan IImu Politik (FISIP) dan Fakultas Ekonomi (FEKON) terus meningkat setiap masa registrasi (Tabel 2). Penurunan jumlah mahasiswa dapat dijustifikasi sebagai salah satu indikator rendahnya loyalitas atau retensi mahasiswa.

Tabel 2. Jumlah registrasi mahasiswa

\begin{tabular}{lccccc}
\hline \multirow{2}{*}{ Fakultas } & \multicolumn{5}{c}{ Masa Registrasi } \\
\cline { 2 - 6 } & $\mathbf{2 0 1 3 . 1}$ & $\mathbf{2 0 1 3 . 2}$ & $\mathbf{2 0 1 4 . 1}$ & $\mathbf{2 0 1 4 . 2}$ & $\mathbf{2 0 1 5 . 1}$ \\
\hline FKIP & 283542 & 268283 & 261720 & 245819 & 234559 \\
FMIPA & 2394 & 2881 & 2691 & 3203 & 3152 \\
FISIP & 57739 & 58862 & 55100 & 53807 & 50816 \\
FEKON & 15950 & 19740 & 19710 & 22489 & 23156 \\
PASCASARJANA & 1576 & 1614 & 1256 & 1883 & 1653 \\
\hline \multicolumn{1}{c}{ Jumlah } & $\mathbf{3 6 1 \mathbf { 2 0 1 }}$ & $\mathbf{3 5 1 3 8 0}$ & $\mathbf{3 4 0 4 7 7}$ & $\mathbf{3 2 7} \mathbf{2 0 1}$ & $\mathbf{3 1 3} \mathbf{3 3 6}$ \\
\hline
\end{tabular}

Sumber: BAAPM UT (2015)

Ketatnya persaingan memaksa perguruan tinggi untuk fokus terhadap retensi siswa. Pertumbuhan sistem e-learning telah meningkatkan kompetisi di antara institusi pendidikan tinggi dan mengurangi hambatan keluar bagi siswa (Tam dan Werner 2005). Pesaing tidak hanya berasal dari perguruan tinggi yang ada di Indonesia, tetapi juga berasal dari perguruan tinggi di luar negeri. Kepuasan dan loyalitas siswa terhadap sistem e-learning telah mendapat perhatian besar dari institusi pendidikan (Tam dan Werner 2005). Carvalho dan de Oliveira Mota (2010) percaya bahwa hubungan berkelanjutan dengan siswa setelah kelulusan dan pembentukan loyalitas siswa berguna bagi kesinambungan keuangan perguruan tinggi. Oleh karena itu, UT sebagai perguruan tinggi negeri yang sebagian besar biaya operasionalnya berasal dari dana masyarakat berupa SPP perlu memperhatikan loyalitas mahasiswa secara lebih cermat. Selain itu, biaya mempertahankan siswa yang ada lebih murah daripada mencari siswa baru. Siswa yang loyal mau merekomendasikan perguruan tinggi tempatnya menuntut ilmu sebelum dan sesudah kelulusan (Hennig-Thurau et al. 2001).

Menurut Mohamad dan Awang (2009), loyalitas di lingkungan pendidikan tinggi terdiri dari dimensi sikap dan perilaku. Loyalitas sikap berbentuk kesediaan siswa memberikan word of mouth dan rekomendasi positif kepada keluarga, teman, dan relasi dimanapun berada. Sedangkan loyalitas perilaku dikaitkan dengan kemauan 
siswa menuntaskan kuliahnya di perguruan tinggi tempatnya menuntut ilmu dan niat siswa untuk melakukan studi lanjut di perguruan tinggi yang sama.

Banyak sekali faktor anteseden loyalitas, sehingga tidak mungkin peneliti untuk menguji pengaruh seluruh faktor secara gabungan dan simultan. Penelitian ini mengadopsi penelitian yang dilakukan Hennig-Thurau et al. (2001), Helgesen dan Nesset (2007) dan Akaparanich (2006) dengan menempatkan kepuasan dan reputasi sebagai perantara untuk memahami hubungan niat loyalitas. Akaparanich (2006) dan Hennig-Thurau et al. (2001) menemukan hubungan signifikan antara kepuasan, komitmen dan loyalitas dengan pelanggan dan pekerja jasa. Oleh karena itu, tujuan utama dari penelitian ini adalah sebagai berikut : 1) Menganalisis karakteristik pengguna tutorial online dan 2) Menguji interelasi diantara anteseden loyalitas yang terdiri dari kualitas jasa, komitmen, kepuasan, dan reputasi.

Beberapa peneliti percaya bahwa sikap kepuasan dibentuk oleh pelanggan ketika nilai yang diterima dari produk melebihi harapan pra-pembelian (Oliver 1980). Sebuah cara yang efektif untuk mengukur kepuasan pengguna adalah dengan menilai hubungan antara kepuasan pelanggan dan kualitas pelayanan (Pitt et al. 1995). Athiyaman (1997) dan DeShields et al. (2005) telah meneliti kepuasan siswa dalam konteks kepuasan pelanggan dan kualitas layanan. Kualitas layanan adalah sejauh mana suatu layanan memenuhi kebutuhan pelanggan (Wiesniewski dan Donnelly 1996). Kualitas layanan adalah perbedaan antara ekspektasi layanan pelanggan dan pelayanan yang dirasakan (Parasuraman et al. 1985). Ketidakpuasan terjadi ketika ekspektasi lebih besar dari kinerja dan kualitas yang dirasakan kurang memuaskan (Parasuraman et al. 1985). Kepuasan pelanggan dapat memediasi hubungan antara persepsi kualitas dan loyalitas pelanggan (Hsu et al. 2008).

Institusi pendidikan tinggi sering dikonseptualisasikan sebagai bagian dari industri jasa. Oleh karena itu, institusi pendidikan tinggi memberikan perhatian lebih pada pemenuhan harapan dan kebutuhan mahasiswa sebagai pelanggan (DeShields et al. 2005). Athiyaman (1997) dan DeShields et al. (2005) telah meneliti kepuasan siswa dalam konteks kepuasan pelanggan dan kualitas jasa. Athiyaman (1997) menemukan bahwa karakteristik jasa adalah 1) penekanan pada pengajaran siswa dengan baik; 2) kesediaan staf untuk konsultasi siswa; 3) layanan perpustakaan; 4) fasilitas komputasi; 5) fasilitas rekreasi; 6) ukuran kelas; 7) tingkat dan kesulitan konten subjek; dan 8) beban kerja siswa. DeShields et al. (2005) menyatakan bahwa siswa yang tidak puas akan mengambil matakuliah lebih sedikit atau sepenuhnya meninggalkan perkuliahan. DeShields et al. (2005) percaya bahwa adanya kompetisi yang ketat di pasar pendidikan tinggi, universitas harus mulai menilai dan mengadopsi strategi orientasi pemasaran yang memenuhi kebutuhan pasar. Mereka mendapat manfaat dari memahami kebutuhan pelanggan, memodifikasi dan meningkatkan jasa agar berhasil memberikan layanan berkualitas tinggi. Dalam pasar yang kompetitif diperlukan pemahaman menyeluruh tentang pasar sasaran termasuk siswa dan pemangku kepentingan.

Josang et al. (2007) mendefinisikan reputasi sebagai apa yang umumnya dikatakan atau dipercaya tentang karakter atau pendirian seseorang atau sesuatu. Reputasi bisa berupa persepsi keseluruhan pelanggan terhadap perusahaan. Kepuasan pelanggan dan reputasi merek adalah bagian dari prinsip-prinsip loyalitas (Selnes 
1993). Menurut Herbig dan Milewicz (1993), reputasi adalah jumlah interaksi keseluruhan antara entitas dan berbagai pihak sepanjang waktu. Reputasi tidak diperoleh dalam waktu singkat, tetapi melibatkan waktu yang cukup panjang. Wang et al. (2003) menyatakan produk dan jasa berkualitas tinggi meningkatkan reputasi.

Komitmen dianggap sebagai faktor kunci kesuksesan jangka panjang (Gundlach et al. 1995). Komitmen didefinisikan sebagai keinginan mendalam untuk menjaga hubungan yang berharga (Anderson dan Weitz 1992). Komitmen dan loyalitas dianggap saling berhubungan (Pritchard et al. 1999). Selain itu, perilaku pelanggan setia dapat diukur dengan komitmen dan hubungan positif yang ada antara komitmen pelanggan dan pembelian barang (Bowen dan Shoemaker 2003). Komitmen dan kepuasan berhubungan juga, mengingat komitmen dapat menyebab-kan kepuasan (Ben-Bakr et al. 1995). Secara logika, komitmen berhubungan dengan reputasi. Komitmen dianggap sebagai jembatan antara reputasi perusahaan dengan niat perilaku pelanggan (Keh dan Xie 2009).

Kepuasan pelanggan dan reputasi merek adalah salah satu prinsip loyalitas (Selnes 1993). Selnes (1993) menyatakan reputasi merek dan kepuasan berpengaruh terhadap loyalitas secara terpisah. Pelanggan mungkin setia bila merasa puas dan berniat untuk menjaga hubungan (Mokhtar et al. 2011). Terdapat hubungan positif antara kepuasan pelanggan dan loyalitas (Anderson dan Sullivan 1993; Mokhtar et al. 2011).

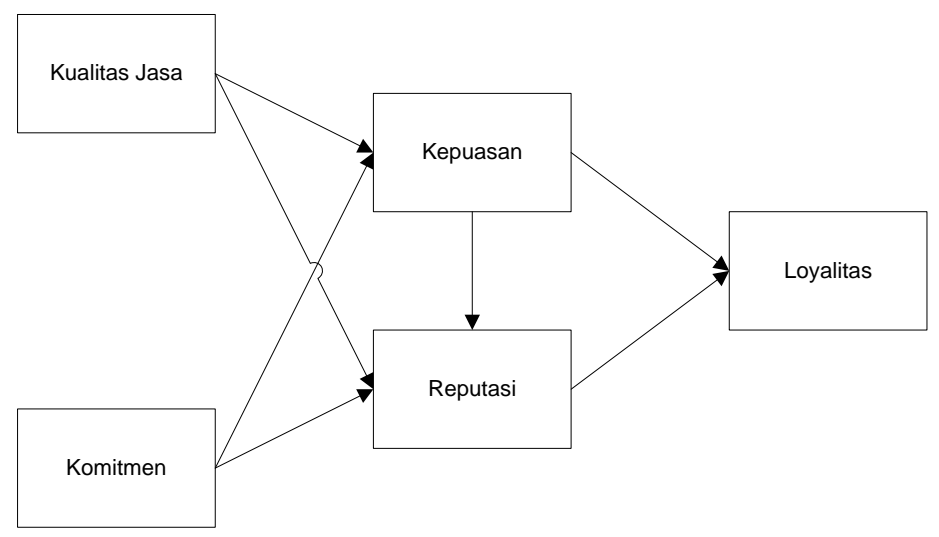

Gambar 1. Model konseptual

Adapun hipotesis yang dapat diajukan dalam penelitian ini berdasarkan model konseptual di atas yaitu sebagai berikut :

$\mathrm{H} 1$ : kualitas jasa berpengaruh terhadap kepuasan mahasiswa

$\mathrm{H} 2$ : kualitas jasa berpengaruh terhadap reputasi

H3 : komitmen berpengaruh terhadap kepuasan

$\mathrm{H} 4$ : komitmen berpengaruh terhadap reputasi

$\mathrm{H} 5$ : kepuasan berpengaruh terhadap reputasi

$\mathrm{H} 6$ : kepuasan berpengaruh terhadap loyalitas

$\mathrm{H} 7$ : reputasi berpengaruh terhadap loyalitas 


\section{Metode Penelitian}

Penelitian dilakukan pada mahasiswa UT peserta Tuton masa registrasi 2015.1. Penelitian ini berlangsung selama 2 bulan dari mulai Maret 2015 hingga April 2015. Pengambilan sampel dilakukan selama 4 minggu, dimulai dari minggu ketiga Maret hingga pertengahan April 2015. Sampel berasal dari 4 fakultas (FKIP, FMIPA, FISIP, dan FEKON) dan 1 Program Pascasarjana.

Data penelitian ini berasal dari data primer dan data sekunder yang bersifat kuantitatif dan kualitatif. Data primer merupakan data yang dikumpulkan peneliti di lapangan berasal dari pembagian kuesioner dan wawancara pihak terkait. Sedangkan data sekunder berasal dari berbagai literatur, buku, artikel dan bahan-bahan terkait lainnya.

Penelitian ini menggunakan metode survei dengan teknik pengumpulan data melalui wawancara langsung dengan pihak terkait. Populasi penelitian adalah mahasiswa peserta tutorial online. Metode pengambilan sampel yang digunakan dalam penelitian ini adalah non-probability sampling dengan teknik judgemental sampling. Kedua metode dan teknik tersebut digunakan karena pertimbangan peneliti berdasarkan kemudahan memperoleh sampel sesuai dengan kriteria dan sampel yang dipilih dapat menjawab kuesioner dengan lebih baik.

Pengumpulan data dilakukan menggunakan kuesioner berskala likert 1-5. Kuesioner dikembangkan berdasarkan indikator penelitian Hennig-Thurau et al. (2001), Akaparanich (2006) dan Helgesen dan Nesset (2007). Analisis multivariat yang digunakan adalah Structural Equation Modelling (SEM), pertimbangan analisis ini merupakan perluasan dari beberapa teknik multivariat termasuk multiregresi dan analisis faktor yang mampu menjelaskan hubungan variabel dependen secara simultan.

Tabel 3. Kuesioner

\begin{tabular}{ll}
\hline No. & \\
\hline 1. & Kualitas Jasa \\
2. & Diskusi dan tugas yang diberikan relevan dengan materi inisiasi yang tersedia \\
3. & Tutor memberikan umpan balik yang baik dan cepat \\
4. & Tuton yang diiikuti memberikan fasilitas hubungan secara real time seperti chatting, skype, dll \\
5. & Tersedia sarana interaksi dengan sesama peserta tuton melalui forum diskusi, forum komunitas atau \\
& grup media sosial seperti whatsapp, blackberry messenger atau facebook \\
\hline & Komitmen \\
6. & Saya berkomitmen tinggi dengan UT \\
8. & Saya berkomitmen tinggi dengan program studi yang saya pilih \\
\hline & Saya berkomitmen tinggi dengan matakuliah yang saya ikuti \\
9. & Kepuasan \\
10. & Saya merasa puas dengan pelayanan tutorial online \\
11. & Saya akan menyampaikan hal-hal positif tentang UT kepada orang lain \\
12. & Saya merasakan kepuasan kuliah di UT \\
\hline & Reputasi \\
13. & UT memiliki reputasi yang baik \\
14. & Program studi yang Anda pilih memiliki reputasi yang baik \\
\hline & Loyalitas \\
15. & Saya akan merekomendasikan UT kepada teman-teman dan kerabat lainnya \\
16. & Saya akan tetap melanjutkan kuliah di UT hingga selesai \\
17. & Apabila mendapat kesempatan studi lanjut, saya akan kembali kuliah di UT di masa mendatang \\
\hline
\end{tabular}


Berkaitan dengan identifikasi masalah penelitian yang akan menentukan hubungan atau pengaruh dari beberapa variabel terhadap loyalitas mahasiswa dan sesuai dengan teknik analisis yang digunakan, maka jumlah sampel yang acceptable adalah minimal 5-10 kali jumlah pertanyaan, yaitu 10x17=170. Jumlah ini merupakan ukuran sampel yang diperlukan melalui SEM dengan metode estimasi Maximum Likelihood (MLE). MLE merupakan prosedur estimasi yang umum digunakan dalam SEM untuk memberikan suatu hasil yang valid (Hair et al. 1998). Untuk memudahkan perhitungan ukuran sampel dibulatkan menjadi 200 (Tabel 4). Selanjutnya, ukuran sampel yang dipakai pada setiap objek penelitian dalam observasi adalah dengan alokasi proporsional atau pengambilan sampel minimal yang terbesar (maximin) dengan rumus menurut Nazir (1999) :

$$
n i=\frac{N i}{N} \times \mathrm{n}
$$

Keterangan:

ni : jumlah sampel mahasiswa tiap jenis mahasiswa

$\mathrm{N}$ : jumlah populasi secara keseluruhan

$\mathrm{Ni}$ : jumlah populasi masing-masing jenis mahasiswa

$\mathrm{n} \quad$ : jumlah sampel dari populasi

Tabel 4. Jumlah sampel minimum

\begin{tabular}{lcc}
\hline \multicolumn{1}{c}{ Fakultas } & Jumlah Mahasiswa & Jumlah Sampel Minimum \\
\hline FKIP & 234559 & 150 \\
FMIPA & 3152 & 2 \\
FISIP & 50816 & 32 \\
FEKON & 23156 & 15 \\
PASCASARJANA & 1653 & 1 \\
\hline \multicolumn{1}{c}{ Jumlah } & $\mathbf{3 1 3 3 3 6}$ & $\mathbf{2 0 0}$ \\
\hline
\end{tabular}

Sumber : BAAPM UT 2015

\section{Hasil Dan Pembahasan}

III.1. Gambaran Umum Universitas Terbuka

UT adalah Perguruan Tinggi Negeri (PTN) ke-45 di Indonesia yang berdiri pada tahun 1984. UT menerapkan sistem pendidikan terbuka dan jarak jauh (SPJ) dalam pelaksanaan proses pendidikannya. Sistem belajar ini terbukti efektif untuk meningkatkan daya jangkau dan pemerataan kesempatan pendidikan tinggi yang berkualitas bagi semua warga negara Indonesia, termasuk mereka yang tinggal di daerah-daerah terpencil.

Hingga saat ini, UT memiliki kantor Unit Program Belajar Jarak Jauh (UPBJJ) di 37 kota yang tersebar di 33 propinsi. Pada akhir tahun 2014, UT terdiri dari 4 fakultas yaitu FKIP, FISIP, FEKON dan FMIPA dan 1 program pascasarjana. Sebanyak 44 program studi studi ditawarkan UT dengan komposisi 3 jenjang diploma, 33 jenjang sarjana, dan 8 jenjang magister. Jumlah mahasiswa aktif UT tahun 2014.2 sebesar 426503 orang, sedangkan mahasiswa registrasi rerata persemester 333501 orang. Dengan jumlah mahasiswa sebesar itu, UT dimasukkan dalam The Top Ten Mega Universities of the World. 


\section{III.2. Karakteristik Responden}

Karakteristik responden diuraikan memuat jenis kelamin, umur, status pernikahan, pekerjaan, pendidikan terakhir, masa studi yang telah ditempuh di UT, fakultas, frekuensi mengakses Tuton, kesesuaian biaya dengan manfaat yang diperoleh, keterampilan komputer menjadi kendala untuk berpartisipasi dalam tuton, dan tempat mengases Tuton.

Berdasarkan hasil pembagian kuesioner kepada mahasiswa UT peserta Tuton masa registrasi 2015.1 yang berasal dari 4 fakultas (FKIP, FMIPA, FISIP, dan FEKON) dan 1 Program Pascasarjana, terkumpul 536 kuesioner yang dapat diolah menjadi data penelitian. Adapun profil responden yang mengisi kuesioner adalah sebagai berikut.

Berdasarkan jenis kelamin, sebagian besar responden yang terlibat dalam penelitian ini adalah pria, dengan usia produktif yaitu antara 21-25 tahun, dan sebagian besar responden sudah menikah. Paling banyak responden berprofesi sebagai pegawai swasta yaitu sebesar $44.2 \%$ dengan tingkat pendidikan terakhir adalah SMA. Hal ini dikarenakan mahasiswa UT sebagian besar adalah lulusan SMA. Namun demikian ada juga yang sudah menempuh pendidikan diploma, sarjana, dan pascasarjana. Sebagian besar mahasiswa UT telah menempuh masa studi selama 2-4 semester, responden terbanyak adalah mahasiswa dari FKIP.

Frekuensi mengakses Tuton, paling sering mahasiswa mengakses Tuton sebanyak 2-3 hari sekali namun demikian ada juga mahasiswa yang mengakses Tuton setiap hari. Sebagian besar mahasiswa menganggap bahwa biaya yang dikeluarkan untuk Tuton sesuai dengan manfaat yang diperoleh. Namun demikian, ada juga mahasiswa yang menganggap bahwa biaya yang dikeluarkan tidak sesuai dengan manfaat yang diperoleh. Selain itu dalam hal keterampilan komputer, ternyata sebesar $27.4 \%$ mahasiswa Tuton masih merasakan kendala dalam keterampilan menggunakan komputer, namun sebagian besar mahasiswa Tuton merasakan tidak ada kendala dalam keterampilan menggunakan komputer. Dari angka ini, ternyata masih cukup besar mahasiswa yang mengalami kendala dalam penggunaan komputer. Sebagian besar mahasiswa mengakses tuton dari rumah, namun demikian ada juga mahasiswa yang mengakses dari kantor dan warnet.

\section{III.3. Analisis Structural Equation Modelling (SEM)}

Pendekatan two step approach digunakan dalam penelitian ini. Tahap pertama adalah merespesifikasikan sebuah model hybrid sebagai sebuah model Confirmatory Factor Analysis (CFA). Kemudian tahap kedua adalah menambahkan model struktural asli pada model CFA hasil tahap pertama untuk menghasilkan model hybrid. Sebelum data dianalisis dengan SEM, dilakukan uji validitas dan reliabilitas menggunakan CFA dengan bantuan Software Linear Structural Relationship (LISREL) 8.7.

1. Uji Validitas dan Reliabilitas

Pada tahap pertama, analisis model pengukuran dilakukan terhadap setiap model pengukuran atau konstruk secara terpisah melalui evaluasi terhadap validitas dan reliabilitas model pengukuran. Kedua evaluasi tersebut adalah nilai-t muatan faktor (factor loading) lebih besar dari nilai kritis $(\geq 1.96)$ dan muatan faktor standar (standardized factor loadings) $\geq 0.50$ (Igbaria et al. 1997 dalam Wijanto 2008). 
Seluruh variabel teramati memiliki validitas yang baik karena memiliki nilai $\quad \mathrm{t}$ value > 1.96 kecuali variabel "saya merasa puas dengan pelayanan Tuton", "UT memiliki reputasi yang baik", dan "saya akan merekomendasikan UT kepada temanteman dan kerabat lainnya". Sedangkan nilai standardized loading factor (SLF) lebih besar dari 0.50 kecuali diskusi dan tugas yang diberikan relevan dengan materi inisiasi yang tersedia. Walaupun bernilai kurang dari 0.50 tetap dianggap valid karena masih di atas 0.30. Selain itu, dari estimasi standardize solution dapat diperoleh uji reliabilitas atau konsistensi suatu pengukuran. Reliabilitas kualitas jasa, komitmen, kepuasan, reputasi dan loyalitas dilihat pada nilai $\mathrm{CR}>0.7$ dan $\mathrm{VE}>0.5$ yang menunjukkan reliabilitas baik.

\section{Uji Kecocokan Seluruh Model}

Setelah diperoleh variabel teramati yang valid dan reliabel, maka tahap kedua analisis SEM two step approach dapat dilaksanakan. Tahap kedua dilakukan dengan menambahkan model struktural asli pada model CFA hasil tahap pertama untuk menghasilkan model hybrid dengan melakukan uji kecocokan keseluruhan model SEM dan analisis model struktural.

Tabel 5. Hasil uji kecocokan keseluruhan model SEM

\begin{tabular}{llll}
\hline \multicolumn{1}{c}{ Ukuran GoF } & \multicolumn{1}{c}{ Target Tingkat Kecocokan } & \multicolumn{1}{c}{ Hasil Estimasi } & Tingkat Kecocokan \\
\hline Chi-Square & Nilai yang kecil & $\mathrm{X}^{2}=524.42(\mathrm{P}=0.0)$ & Kurang baik \\
$\mathrm{P}$ & $\mathrm{P}>0,05$ & & \\
NCP & Nilai yang kecil & 413.42 & Kurang baik \\
Interval & Interval yang sempit & $(345.91 ; 488.46)$ & \\
RMSEA & RMSEA $\leq 0.08$ & 0.084 & Kurang baik \\
p (close fit) & $\mathrm{p} \geq 0.50$ & $\mathrm{p}=0.00$ & \\
ECVI & Nilai yang kecil dan dekat dengan & $\mathrm{M}=1.15$ & Baik \\
& ECVI saturated & $\mathrm{S}=0.58$ & \\
& & $\mathrm{I}=19.31$ & \\
AIC & $\mathrm{Nilai}$ yang kecil dan dekat dengan & $\mathrm{M}=608.42$ & \\
& $\mathrm{AIC}$ saturated & $\mathrm{S}=306.00$ & \\
& & $\mathrm{I}=10253.32$ & Baik \\
CAIC & $\mathrm{Nilai}$ yang kecil dan dekat dengan & $\mathrm{M}=830.04$ & \\
& $\mathrm{CAIC}$ saturated & $\mathrm{S}=1113.33$ & \\
& & $\mathrm{I}=10343.03$ & Baik \\
NFI & $\mathrm{NFI} \geq 0.90$ & 0.95 & Baik \\
NNFI & $\mathrm{NNFI} \geq 0.90$ & 0.95 & Baik \\
CFI & $\mathrm{CFI} \geq 0.90$ & 0.96 & Baik \\
IFI & $\mathrm{IFI} \geq 0.90$ & 0.96 & Baik \\
RFI & $\mathrm{RFI} \geq 0.90$ & 0.94 & Kurang baik \\
CN & $\mathrm{CNI} \geq 200$ & 155.87 & Kurang baik \\
RMR & Standardized RMR $\leq 0.05$ & 0.081 & Kaik \\
GFI & GFI $\geq 0.90$ & 0.90 & \\
AGFI & $\mathrm{AGFI} \geq 0.90$ & 0.86 & \\
\hline
\end{tabular}

Sumber: Data diolah (2014)

Pada uji kecocokan keseluruhan model SEM (overall model fit) terdiri atas beberapa parameter yang pada umumnya dikelompokkan menjadi dua, yaitu uji statistik dan uji non statistik. Hair et al. (1998) mengemukakan bahwa dalam analisis SEM tidak ada alat uji statistik tunggal untuk mengukur atau menguji hipotesis 
mengenai keseluruhan model sehingga digunakan beberapa ukuran derajat kesesuaian yang dapat digunakan secara saling mendukung.

Setelah modifikasi dilakukan dengan hati-hati, didapat nilai dari pengujian kesesuaian keseluruhan model terhadap indeks-indeks seperti ditunjukkan pada Tabel 4. Berdasarkan nilai yang didapat, keseluruhan model yang dibangun memiliki nilai yang sesuai sehingga model yang dibangun dapat menjelaskan informasi empiris sesuai data yang dikumpulkan. Uji kecocokan keseluruhan model SEM dapat dilihat pada Tabel 5 yang menunjukkan hasil yang cukup baik. Dari Tabel 5 terlihat bahwa 9 dari 15 ukuran GoF menunjukkan kecocokan baik, sedangkan 6 ukuran GoF lainnya menunjukkan kecocokan yang kurang baik. Sehingga dapat disimpulkan bahwa kecocokan keseluruhan model adalah baik.

\section{Analisis Model Struktural}

Setelah melakukan uji kecocokan keseluruhan model SEM, maka langkah selanjutnya adalah melakukan analisis model struktural. Pada Gambar 2 (Model tvalue) menunjukkan signifikansi pengaruh antara konstruk. Dilihat dari 7 relasi di antara kelima konstruk variabel laten, 6 di antaranya menunjukkan pengaruh yang signifikan. Signifikansi pengaruh terlihat dari besarnya nilai t-hitung di atas 1.96, kecuali pengaruh komitmen terhadap reputasi memiliki nilai t-hitung $<1.96$.

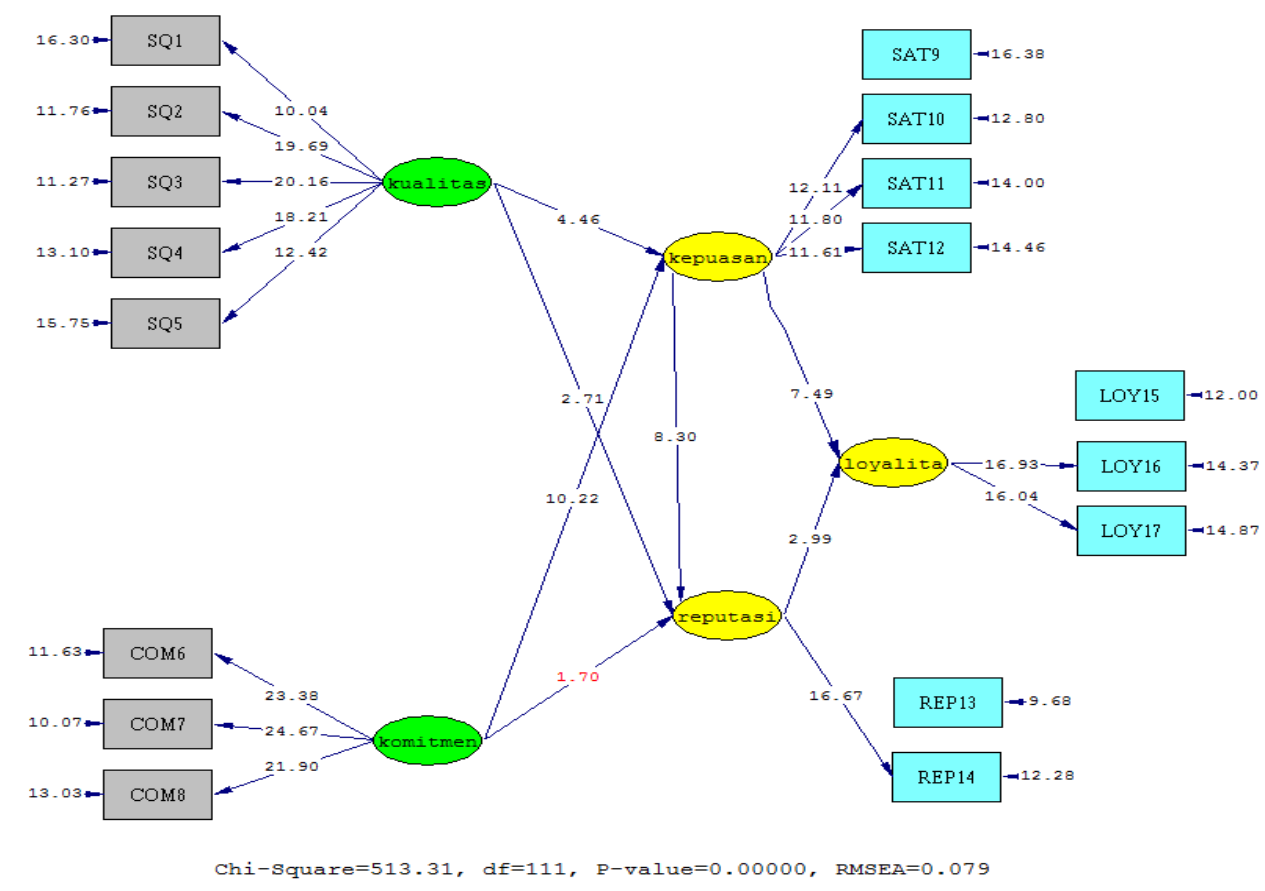

Gambar 2. Diagram lintas model hasil t-value

Konstruk kualitas jasa memiliki pengaruh signifikan dan positif terhadap kepuasan dengan nilai t-value 4.46. Kemudian konstruk kualitas jasa juga memiliki pengaruh signifikan dan positif terhadap reputasi dengan nilai t-value sebesar 2.71 . Sedangkan konstruk komitmen juga memiliki pengaruh signifikan dan positif terhadap kepuasan dengan nilai t-value sebesar 10.22. Namun konstruk komitmen terhadap 
reputasi tidak berpengaruh positif dan signifikan terhadap loyalitas mahasiswa karena $\mathrm{t}$-value kurang dari 1.96 ( $\mathrm{t}$-value $=1.70)$.

Kemudian konstruk kepuasan memiliki pengaruh signifikan dan positif terhadap reputasi dan loyalitas dengan nilai t-value masing-masing sebesar 8.30 dan 7.49. Konstruk reputasi memiliki pengaruh signifikan dan positif terhadap loyalitas dengan nilai t-value sebesar 2.99. Di antara keenam pengaruh signifikan tersebut, pengaruh terbesar dimiliki kepuasan terhadap loyalitas mahasiswa sebesar 0.71 (Gambar 3). Diikuti pengaruh kepuasan terhadap reputasi yaitu sebesar 0.69 dan komitmen terhadap kepuasan sebesar 0.64. Kemudian pengaruh reputasi terhadap loyalitas mahasiswa sebesar 0.24 dan pengaruh kualitas terhadap kepuasan dan reputasi sebesar 0.19 dan 0.12 .

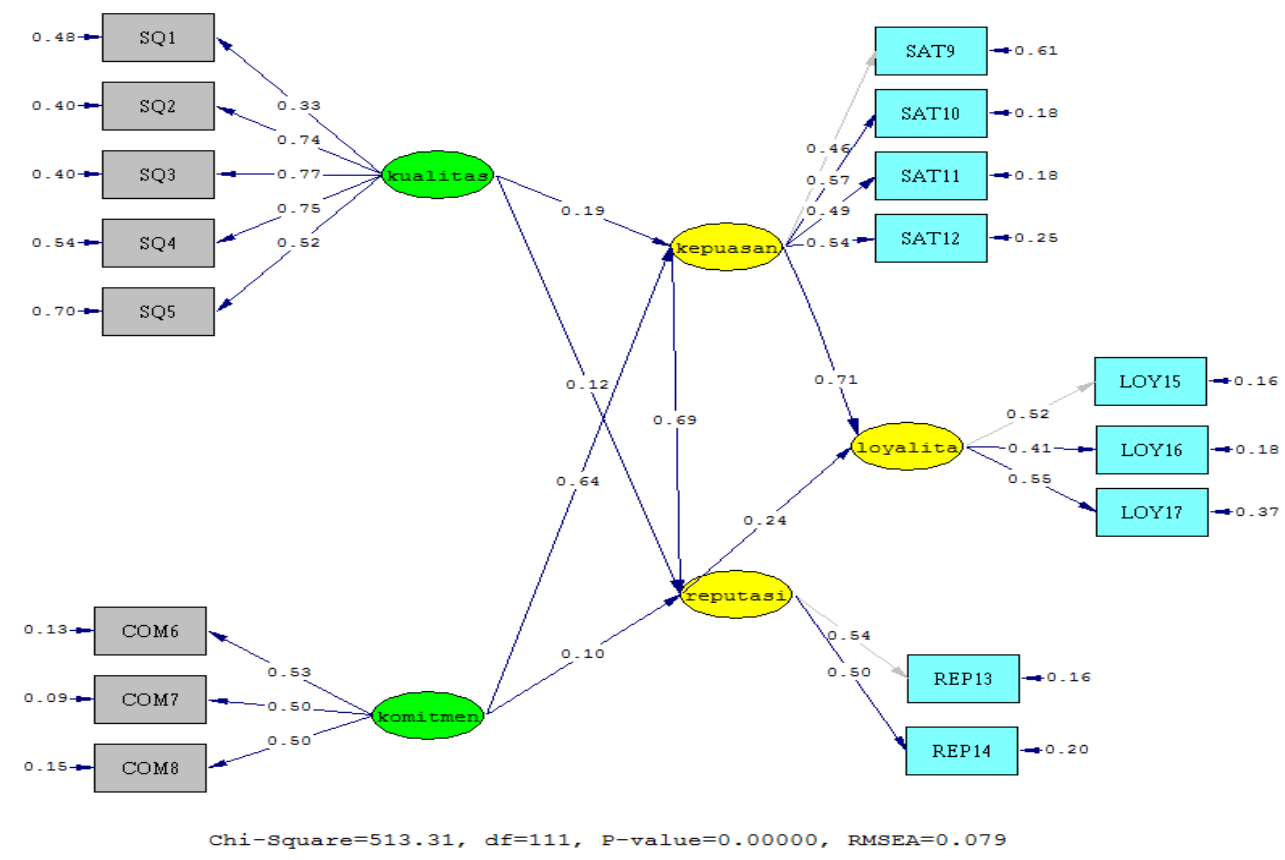

Gambar 3. Diagram lintas model hasil Estimates

Tabel 6. Resume uji hipotesis

\begin{tabular}{|c|c|c|c|c|}
\hline Hipotesis & Path & Estimasi & Nilai - t & Kesimpulan \\
\hline 1 & $\begin{array}{l}\text { Kualitas jasa terhadap } \\
\text { kepuasan }\end{array}$ & 0.19 & 4.46 & Signifikan (Hipotesis 1 diterima) \\
\hline 2 & $\begin{array}{l}\text { Kualitas jasa terhadap } \\
\text { reputasi }\end{array}$ & 0.12 & 2.71 & Signifikan (Hipotesis 2 diterima) \\
\hline 3 & $\begin{array}{l}\text { Komitmen terhadap } \\
\text { kepuasan }\end{array}$ & 0.64 & 10.22 & Signifikan (Hipotesis 3 diterima) \\
\hline 4 & Komitmen terhadap reputasi & 0.10 & 1.70 & $\begin{array}{l}\text { Tidak Signifikan (Hipotesis } 4 \text { tidak } \\
\text { diterima) }\end{array}$ \\
\hline 5 & Kepuasan terhadap reputasi & 0.69 & 8.30 & Signifikan (Hipotesis 5 diterima) \\
\hline 6 & Kepuasan terhadap loyalitas & 0.71 & 7.49 & Signifikan (Hipotesis 6 diterima) \\
\hline 7 & Reputasi terhadap loyalitas & 0.24 & 2.99 & Signifikan (Hipotesis 7 diterima) \\
\hline
\end{tabular}

Sumber: Data diolah (2014) 
a. Pengaruh Kualitas Jasa terhadap Kepuasan dan Reputasi

Berdasarkan Tabel 6, sesuai dengan prediksi terlihat bahwa kualitas jasa berpengaruh signifikan terhadap kepuasan. Hal ini sejalan dengan penelitian Bakti dan Sumaedi (2013) dan Chang dan Wang (2011). Selain itu, kualitas jasa berpengaruh signifikan terhadap reputasi. Hasil ini mendukung penelitian Deghan et al. (2014). Indikator-indikator kualitas jasa yang perlu diperhatikan UT sebagai perguruan tinggi jarak jauh antara lain meliputi umpan balik yang diberikan tutor, kemudahan menghubungi tutor, dan ketersediaan fasilitas interaksi realtime antara tutor dan peserta Tuton.

\section{b. Pengaruh Komitmen terhadap Kepuasan dan Reputasi}

Hasil penelitian ini menunjukkan komitmen berpengaruh signifikan terhadap kepuasan $\left(\mathrm{H}_{3}\right)$ tetapi tidak berpengaruh terhadap reputasi $\left(\mathrm{H}_{4}\right)$. Hipotesis 3 konsisten dengan penelitian sebelumnya yang dilakukan Deghan et al. (2014). Sedangkan hipotesis 4 bertentangan dengan penelitian yang sama. Penelitian Deghan et al. (2014) menyatakan lemahnya hubungan antara komitmen terhadap reputasi pada lingkungan program online. Hal ini mengkonfirmasi penelitian Helgesen dan Nesset (2007) pada program pendidikan konvensional. Oleh karena itu, dapat dipahami sebagai suatu kewajaran apabila pada kasus UT hasil penelitian menunjukkan bahwa komitmen tidak berpengaruh terhadap reputasi.

\section{c. Pengaruh Kepuasan Terhadap Reputasi dan Loyalitas}

Tabel 6 menunjukkan $\mathrm{H}_{5}$ dan $\mathrm{H}_{6}$ terbukti berpengaruh signifikan. Penelitian ini membuktikan bahwa kepuasan berpengaruh pada reputasi dan loyalitas. Hasil ini sejalan dengan temuan Deghan et al. (2014) tentang pengaruh kepuasan pada reputasi, dan penelitian Bakti dan Sumaedi (2013) terkait pengaruh kepuasan terhadap loyalitas. Kepuasan mahasiswa pengguna tutorial online meliputi antara lain ketepatan putusan memilih kuliah di UT, niat menyampaikan hal-hal positif tentang UT kepada orang lain dan kepuasan terhadap layanan Tuton.

\section{d. Pengaruh Reputasi terhadap Loyalitas}

Hipotesis 6 menunjukkan pengaruh signifikan reputasi terhadap loyalitas. Penelitian ini mengkonfirmasi hasil penelitian sebelumnya yang dilakukan Deghan et al. (2014). Hal ini berarti semakin tinggi reputasi UT secara otomatis akan meningkatkan loyalitas mahasiswanya. Oleh karena itu, UT perlu memperhatikan reputasinya baik sebagai institusi pendidikan tinggi maupun program studi yang dimiliki.

Besarnya kontribusi variabel teramati terhadap pembentukan masing-masing konstruk dapat dilihat dari nilai model struktural estimates. Besarnya pengaruh masing-masing variabel diperoleh dengan mengalikan faktor muatan dengan koefisien konstruk variabel yang dibentuk.

Pada relasi kualitas jasa terhadap kepuasan dan kualitas jasa terhadap reputasi, kontribusi tertinggi yaitu tutor memberikan umpan balik. Kemudian diikuti oleh tutor mudah dihubungi, Tuton yang diikuti memberikan fasilitas hubungan secara realtime dan tersedia sarana interaksi dengan sesama peserta Tuton melalui forum diskusi, forum komunitas atau grup media sosial. Sedangkan kontribusi terendah yaitu diskusi dan tugas relevan dengan materi inisiasi. 
Selanjutnya, pada relasi komitmen terhadap kepuasan kontribusi terbesar terdapat pada mahasiswa berkomitmen tinggi dengan program studi yang dipilih, kemudian diikuti dengan mahasiswa berkomitmen tinggi dengan UT dan mahasiswa berkomitmen tinggi dengan matakuliah yang diikuti.

Tabel 7. Kontribusi variabel teramati terhadap pembentukan konstruk

\begin{tabular}{|c|c|c|c|c|}
\hline $\begin{array}{c}\text { Variabel } \\
\text { Laten/Teramati }\end{array}$ & Pernyataan & $\begin{array}{l}\text { Faktor } \\
\text { Muatan }\end{array}$ & $\begin{array}{l}\text { Koefisien } \\
\text { Konstruk }\end{array}$ & Kontribusi \\
\hline \multicolumn{5}{|l|}{$\begin{array}{c}\text { Kualitas jasa } \\
\text { terhadap kepuasan }\end{array}$} \\
\hline SQ1 & $\begin{array}{l}\text { Diskusi dan tugas relevan dengan } \\
\text { materi inisiasi }\end{array}$ & 0.43 & 0.19 & 0.0817 \\
\hline SQ2 & Tutor mudah dihubungi & 0.76 & 0.19 & 0.1444 \\
\hline SQ3 & Tutor memberikan umpan balik & 0.78 & 0.19 & 0.1482 \\
\hline SQ4 & $\begin{array}{l}\text { Tuton yang diikuti memberikan } \\
\text { fasilitas hubungan secara realtime }\end{array}$ & 0.72 & 0.19 & 0.1368 \\
\hline SQ5 & $\begin{array}{l}\text { Tersedia sarana interaksi dengan } \\
\text { sesama peserta tuton melalui forum } \\
\text { diskusi, forum komunitas atau grup } \\
\text { media sosial }\end{array}$ & 0.52 & 0.19 & 0.0988 \\
\hline \multicolumn{5}{|l|}{$\begin{array}{c}\text { Kualitas jasa } \\
\text { terhadap reputasi }\end{array}$} \\
\hline SQ1 & $\begin{array}{l}\text { Diskusi dan tugas relevan dengan } \\
\text { materi inisiasi }\end{array}$ & 0.43 & 0.12 & 0.0516 \\
\hline SQ2 & Tutor mudah dihubungi & 0.76 & 0.12 & 0.0912 \\
\hline SQ3 & Tutor memberikan umpan balik & 0.78 & 0.12 & 0.0936 \\
\hline SQ4 & $\begin{array}{l}\text { Tuton yang diikuti memberikan } \\
\text { fasilitas hubungan secara realtime }\end{array}$ & 0.72 & 0.12 & 0.0864 \\
\hline SQ5 & $\begin{array}{l}\text { Tersedia sarana interaksi dengan } \\
\text { sesama peserta tuton melalui forum } \\
\text { diskusi, forum komunitas atau grup } \\
\text { media sosial }\end{array}$ & 0.52 & 0.12 & 0.0624 \\
\hline \multicolumn{5}{|l|}{$\begin{array}{c}\text { Komitmen } \\
\text { terhadap kepuasan }\end{array}$} \\
\hline COM6 & Saya berkomitmen tinggi dengan UT & 0.83 & 0.65 & 0.5395 \\
\hline COM 7 & $\begin{array}{l}\text { Saya berkomitmen tinggi dengan } \\
\text { program studi yang saya pilih }\end{array}$ & 0.86 & 0.65 & 0.5590 \\
\hline COM 8 & $\begin{array}{l}\text { Saya berkomitmen tinggi dengan } \\
\text { matakuliah yang saya ikuti }\end{array}$ & 0.79 & 0.65 & 0.5135 \\
\hline \multicolumn{5}{|l|}{$\begin{array}{l}\text { Kepuasan terhadap } \\
\text { reputasi }\end{array}$} \\
\hline SAT9 & $\begin{array}{l}\text { Saya merasa puas dengan pelayanan } \\
\text { tutorial online }\end{array}$ & 0.51 & 0.69 & 0.3519 \\
\hline SAT10 & $\begin{array}{l}\text { Saya merasa melakukan pilihan tepat } \\
\text { dengan kuliah di UT }\end{array}$ & 0.80 & 0.69 & 0.5520 \\
\hline SAT11 & $\begin{array}{l}\text { Saya akan menyampaikan hal-hal } \\
\text { positif tentang UT kepada orang lain }\end{array}$ & 0.76 & 0.69 & 0.5244 \\
\hline SAT12 & Saya merasakan kepuasan kuliah di UT & 0.73 & 0.69 & 0.5037 \\
\hline \multicolumn{5}{|l|}{$\begin{array}{l}\text { Kepuasan terhadap } \\
\text { loyalitas }\end{array}$} \\
\hline SAT9 & $\begin{array}{l}\text { Saya merasa puas dengan pelayanan } \\
\text { tutorial online }\end{array}$ & 0.51 & 0.71 & 0.3621 \\
\hline
\end{tabular}


Lanjutan Tabel 7

\begin{tabular}{|c|c|c|c|c|}
\hline $\begin{array}{c}\text { Variabel } \\
\text { Laten/Teramati }\end{array}$ & Pernyataan & $\begin{array}{l}\text { Faktor } \\
\text { Muatan }\end{array}$ & $\begin{array}{l}\text { Koefisien } \\
\text { Konstruk }\end{array}$ & Kontribusi \\
\hline SAT10 & $\begin{array}{l}\text { Saya merasa melakukan pilihan tepat } \\
\text { dengan kuliah di UT }\end{array}$ & 0.80 & 0.71 & 0.5680 \\
\hline SAT11 & $\begin{array}{l}\text { Saya akan menyampaikan hal-hal } \\
\text { positif tentang UT kepada orang lain }\end{array}$ & 0.76 & 0.71 & 0.5396 \\
\hline SAT12 & Saya merasakan kepuasan kuliah di UT & 0.73 & 0.71 & 0.5183 \\
\hline \multicolumn{5}{|l|}{$\begin{array}{l}\text { Reputasi terhadap } \\
\text { loyalitas }\end{array}$} \\
\hline REP13 & UT memiliki reputasi yang baik & 0.81 & 0.24 & 0.1944 \\
\hline REP14 & $\begin{array}{l}\text { Program studi yang Anda pilih } \\
\text { memiliki reputasi yang baik }\end{array}$ & 0.75 & 0.24 & 0.18 \\
\hline
\end{tabular}

Sumber: Data diolah

Kemudian pada relasi kepuasan terhadap reputasi dari 4 variabel teramati hanya 3 variabel yang signifikan yaitu mahasiswa merasa melakukan pilihan tepat dengan kuliah di UT, mahasiswa akan menyampaikan hal-hal positif tentang UT kepada orang lain, dan mahasiswa merasakan kepuasan kuliah di UT. Kontribusi terbesar yaitu mahasiswa merasa melakukan pilihan tepat dengan kuliah di UT

Sedangkan relasi kepuasan terhadap reputasi dan kepuasan terhadap loyalitas terdapat 1 variabel teramati yang tidak signifikan, yaitu mahasiswa merasa puas dengan pelayanan Tuton. Oleh karena itu, kontribusi variabel teramati pada relasi ini diperoleh 3 variabel teramati lainnya. Ketiga variabel teramati tersebut yaitu mahasiswa merasa melakukan pilihan tepat dengan kuliah di UT, mahasiswa akan menyampaikan hal-hal positif tentang UT kepada orang lain, dan mahasiswa merasakan kepuasan kuliah di UT. Kontribusi terbesar yaitu mahasiswa merasa melakukan pilihan tepat dengan kuliah di UT.

Pada relasi reputasi terhadap loyalitas, variabel teramati yang signifikan yaitu Program Studi yang mahasiswa pilih memiliki reputasi yang baik. Secara keseluruhan dapat dilihat bahwa kontribusi terbesar dalam penelitian ini adalah mahasiswa merasa melakukan pilihan tepat dengan kuliah di UT, diikuti dengan mahasiswa berkomitmen tinggi dengan Program Studi yang dipilih.

\section{III.4. Implikasi Manajerial}

Kebanyakan penelitian terdahulu fokus terhadap loyalitas siswa sistem pendidikan konvensional. Sedangkan penelitian ini berlatarbelakang pendidikan jarak jauh. Perbedaan latarbelakang memberikan hasil yang sedikit berbeda.

Berdasarkan penelitian, kualitas jasa berpengaruh terhadap kepuasan dan reputasi. Kualitas jasa yang perlu diperhatikan UT sebagai penyedia jasa pendidikan meliputi umpan balik yang diberikan tutor. Dengan adanya umpan balik yang diberikan tutor maka proses pembelajaran Tuton dapat berjalan dengan baik, mahasiswa dapat berinteraksi secara aktif dengan tutor dan materi yang diberikan dapat dibahas dengan cepat. Kemudian, untuk kemudahan menghubungi tutor, maka mahasiswa dapat bertanya atau berdiskusi dengan tutor secara tepat dan cepat. Ketersediaan fasilitas real time antara tutor dan mahasiswa, dan ketersediaan sarana interaksi sesama peserta Tuton melalui forum diskusi, forum komunitas atau grup media sosial 
memberikan kemudahan kepada mahasiswa untuk saling berinteraksi, baik dengan sesama mahasiswa maupun dengan tutor.

Selain kualitas jasa, kepuasan pun dipengaruhi oleh komitmen mahasiswa sebagai peserta Tuton. Komitmen mahasiswa yang terdiri dari komitmen terhadap program studi yang dipilih, komitmen terhadap UT dan komitmen terhadap mata kuliah yang dipilih sangat berpengaruh terhadap kepuasan mahasiswa. Oleh karena itu, UT perlu terus memotivasi mahasiswanya untuk tetap menjaga komitmen menyelesaikan kuliah di UT hingga selesai. Dengan adanya komitmen yang tinggi maka mahasiswa akan berhasil dalam proses pembelajaran jarak jauh. Keberhasilan mahasiswa tergantung dari bagaimana mahasiswa tersebut bertanggungjawab dalam menjalankan studinya. Sehingga mahasiswa yang bertanggungjawab secara otomatis akan membentuk karakter komitmen dan kesetiaan dalam diri mahasiswa UT tersebut.

Kepuasan mahasiswa sebagai pengguna jasa pendidikan yang disediakan UT perlu diperhatikan secara seksama. Menurut hasil penelitian ini, kepuasan berpengaruh signifikan terhadap reputasi dan loyalitas. Dengan adanya rasa puas, mahasiswa menyampaikan hal-hal positif tentang UT kepada orang lain dan mahasiswa akan merasa telah melakukan pilihan yang tepat dengan kuliah di UT. Dengan demikian mahasiswa dapat membangun kesan positif kuliah di UT dan sekaligus juga membangun citra yang positif di masyarakat.

Pada relasi reputasi terhadap loyalitas, faktor yang paling signifikan yaitu reputasi program studi yang mahasiswa pilih. Artinya, semakin baik reputasi program studi maka secara otomatis akan meningkatkan loyalitas mahasiswa terhadap UT secara keseluruhan. Reputasi program studi yang unggul dapat membuat mahasiswa terus bertahan atau loyal terhadap UT dan UT menjadi pilihan utama bagi mahasiswa ataupun calon mahasiswa, baik itu masyarakat umum, perusahaan swasta, institusi pemerintah dan stakeholder lainnya.

\section{Kesimpulan}

Mayoritas pengguna tutorial online berusia antara 21-25 tahun, telah menikah dan bekerja sebagai pegawai swasta. Sesuai dengan persyaratan minimum mahasiswa UT, sebagian besar merupakan lulusan SMA. Telah menempuh masa studi selama 2-4 semester. Tuton diakses mahasiswa sebanyak 2-3 hari sekali. Mahasiswa merasa biaya yang telah dikeluarkan sesuai dengan manfaat yang diperoleh.

Hasil penelitian menunjukkan bahwa kualitas jasa mempengaruhi kepuasan dan reputasi. Hal ini mengindikasikan semakin tinggi kualitas jasa yang diberikan UT, maka kepuasan dan reputasi akan semakin meningkat pula. Kemudian komitmen berpengaruh terhadap kepuasan, tetapi tidak berpengaruh terhadap reputasi. Kepuasan selanjutnya berpengaruh terhadap reputasi dan loyalitas. Semakin tinggi kepuasan mahasiswa, maka reputasi UT dan loyalitas mahasiswa akan otomatis meningkat. Terakhir, reputasi berpengaruh terhadap loyalitas. Seperti halnya kepuasan, semakin baik reputasi UT maka semakin tinggi pula loyalitas mahasiswa terhadap UT.

Dari semua variabel yang memiliki pengaruh terhadap loyalitas, pengaruh terbesar adalah variabel kepuasan mahasiswa. Konstruk kualitas jasa dibentuk oleh 
beberapa faktor di antaranya diskusi dan tugas yang diberikan relevan dengan materi inisiasi yang tersedia, tutor mudah dihubungi melalui message board atau surel, tutor memberikan umpan balik yang baik dan cepat, Tuton yang diikuti memberikan fasilitas hubungan secara real time seperti chatting, skype, atau telepon, dan tersedia sarana interaksi dengan sesama peserta Tuton melalui forum diskusi, forum komunitas atau grup media sosial seperti Whatsapp, Blackberry Messenger atau Facebook.

Konstruk komitmen dibentuk oleh beberapa faktor di antaranya mahasiswa berkomitmen tinggi dengan UT, mahasiswa berkomitmen tinggi dengan program studi yang dipilih, dan mahasiswa berkomitmen tinggi dengan matakuliah yang diikuti. Konstruk kepuasan dibentuk oleh beberapa faktor diantaranya mahasiswa merasa melakukan pilihan tepat dengan kuliah di UT, mahasiswa akan menyampaikan hal-hal positif tentang UT kepada orang lain, mahasiswa merasakan kepuasan kuliah di UT.

Konstruk reputasi dibentuk oleh faktor Program Studi yang dipilih mahasiswa memiliki reputasi yang baik. Konstruk loyalitas dibentuk oleh beberapa faktor di antaranya mahasiswa akan tetap melanjutkan kuliah di UT hingga selesai. Apabila mendapat kesempatan studi lanjut, mahasiswa akan kembali kuliah di UT di masa mendatang.

\section{Daftar Pustaka}

Akaparanich S. 2006. Comparing customer loyalty intentions using trust, satisfaction, and commitment of online mba students versus traditional mba students.[disertasi], Nova Southeastern University, Fort-Lauderdale-Davie, FL.

Anderson E, Weitz BA. 1992. The use of pledges to build and sustain commitmen in distribution channels. Journal of Marketing Research, 29: 18-30.

Anderson EW, Sullivan MW. 1993. The antecedents and consequences of customer satisfaction for firms. Marketing Science, 12(2): 125-143.

Asandimitra. 2004. Pendidikan Tinggi Jarak Jauh. Jakarta (ID): Universitas Terbuka.

Athiyaman A. 1997. Linking student satisfaction and service quality perceptions: The case of university education. European Journal of Marketing, 31(7): 528-540.

Bakti IGMY, Sumaedi S. 2013. An analysis of library customer loyalty - The role of service quality and customer satisfaction, a case study in Indonesia. Library Management, 34 (6/7): 397-414.

Ben-Bakr KA, Al-Shammari IS, Jefri OA, Prasad JN. 1995. Organizational commitment, satisfaction, and turnover in Saudi organizations: A predictive study. Journal of Socio-Economics, 23(4): 449-456.

Bowen JT, Shoemaker S. 2003. Loyalty: A strategic commitment. Cornell Hotel and Restaurant Administration Quarterly, 44 (Nos 5/6): 31-46.

Carvalho SW, de Oliveira Mota M. 2010. The role of trust in creating value and student loyalty in relational exchanges between higher education institutions and their students. Journal of Marketing for Higher Education, 20(1): 145-165.

Chang HH, Wang HW. 2011. The moderating effect of customer perceived value on online shopping behavior. Online Information Review, 35 (3): 333 - 359. 
Daulay P, Zaman B. 2012. Pengembangan model penelusuran diskusi tutorial online melalui aplikasi FAQ (Frequently Ask Question). Jurnal Pendidikan Terbuka dan Jarak Jauh, 13(2): 80-93.

Deghan A, Dugger J, Dobrzykowski D, Balazs A. 2014. The Antecedents of student loyalty in online programs. International Journal of Educational Management, 28(1): 15-35.

DeShields OW Jr, Kara A, Kaynak E. 2005. Determinants of business student satisfaction and retention in higher education: applying Herzberg's two-factor theory. International Journal of Educational Management, 19(2): 128-139.

Gundlach GT, Achrol RS, Mentzer JT. 1995. The structure of commitment in exchange. The Journal of Marketing, 59(1): 78-92.

Hair JF Jr, Anderson RE, Tatham RL, Black WC. 1998. Multivariate Data Analysis, Fifth Edition. New Jersey (US): Prentice Hall.

Helgesen O, Nesset E. 2007. Images, satisfaction and antecedents: Drivers of student loyalty? A case study of a Norwegian University College. International Journal of Educational Management, 21(2): $126-146$.

Hennig-Thurau T, Langer MF, Hansen U. 2001. Modeling and managing student loyalty. Journal of Service Research, 3(4): 331-344.

Herbig P, Milewicz J. 1993. The relationship of reputation and credibility to brand success. Journal of Consumer Marketing, 10(3): 18-24

Hsu GJ, Lin YH, Wei ZY. 2008. Competition policy for technological innovation in an era of knowledge-based economy. Knowledge-Based Systems, 21(8): 826-832.

Josang A, Islam R, Boyd C. 2007. A survey of trust and reputation systems for online service provision. Decision Support Systems, 43(2): 618-644.

Kahiigi EK, Ekenberg L, Hansson H, Tusubira F, Danielson M. 2007. Exploring the elearning state of art. The Electronic Journal of E-Learning, 6(2): 77-88.

Keh HT, Xie Y. 2009. Corporate reputation and customer behavioral intentions: the roles of trust, identification and commitment. Industrial Marketing Management, 38(7): 732-742.

Mohamad M. dan Awang Z. 2009. Building corporate image and securing student loyalty in the Malaysian Higher Learning Industry. The Journal of International Management Studies, 4(1): 30-39.

Mokhtar SS, Maiyaki AA, Mohd Noor Nbt. 2011. The relationship between service quality and satisfaction on customer loyalty in Malaysian mobile communication industry. School of Doctoral Studies (European Union) Journal, 3: 32-38.

Nagel D. 2009. Most college students to take classes online by 2014.[Internet].[diundu h 21 April 2014]. Tersedia pada: http://campustechnology.com/ articles/2009/10/28/most-college-students-to-take-classes-online-by2014.aspx

Nazir M. 1999. Metode Penelitian. Cetakan ketiga. Jakarta (ID): Ghalia Indonesia.

Oliver RL. 1980. A cognitive model of the antecedents and consequences of satisfaction decisions. Journal of Marketing Research, 17: 460-469.

Parasuraman A, Zeithaml VA, Berry L. 1985. A conceptual model of service quality and its implications for future research. Journal of Marketing, 49(4): 41-50

Pitt LF, Watson RT, Kavan CB. 1995. Service quality: a measure of information systems effectiveness. MIS Quarterly, 19(2): 173-187. 
Pritchard MP, Havitz ME, Howard DR. 1999. Analyzing the commitment-loyalty link in service contexts. Journal of the Academy of Marketing Science, 27(3): 333-348.

Selnes F. 1993. An examination of the effect of product performance on brand reputation, satisfaction and loyalty. European Journal of Marketing, 27(9): 19-35.

Tam CM, Werner JM. 2005. Designing and evaluating e-learning in higher education: a review and recommendations. Journal of Leadership and Organizational Studies, 11(2): 15-25.

Wang Y, Lo HP, Hui YV. 2003. The antecedents of service quality and product quality and their influences on bank reputation: evidence from the banking industry in China. Managing Service Quality, 13(1): 72-83.

Wisniewski M, Donnelly M. 1996. Measuring service quality in public sector: The Potential for SERVQUAL. Total Quality Management Journal, 7(4): 357-365.

Wijanto SH. 2008. Structural Equation Modelling dengan LISREL 8.8. Edisi Pertama. Yogyakarta (ID): Graha Ilmu.

Zhang D, Zhao JL, Zhou L, Nunamaker JF Jr. 2004. Can e-learning replace classroom learning?. Communication of the ACM, 47(5): 75-79. 